\title{
Trends and regime shifts in climatic conditions and river runoff in Estonia during 1951-2015
}

\author{
Jaak Jaagus ${ }^{1}$, Mait Sepp ${ }^{1}$, Toomas Tamm ${ }^{2}$, Arvo Järvet ${ }^{1}$, and Kiira Mõisja ${ }^{1}$ \\ ${ }^{1}$ Department of Geography, University of Tartu, Tartu, 51014, Estonia \\ ${ }^{2}$ Department of Water Management, Estonian University of Life Sciences, \\ Tartu, 51014, Estonia \\ Correspondence to: Jaak Jaagus (jaak.jaagus@ut.ee)
}

Received: 8 March 2017 - Discussion started: 20 March 2017

Revised: 8 September 2017 - Accepted: 20 September 2017 - Published: 3 November 2017

\begin{abstract}
Time series of monthly, seasonal and annual mean air temperature, precipitation, snow cover duration and specific runoff of rivers in Estonia are analysed for detecting of trends and regime shifts during 1951-2015. Trend analysis is realised using the Mann-Kendall test and regime shifts are detected with the Rodionov test (sequential $t$-test analysis of regime shifts). The results from Estonia are related to trends and regime shifts in time series of indices of large-scale atmospheric circulation. Annual mean air temperature has significantly increased at all 12 stations by $0.3-0.4 \mathrm{Kdecade}^{-1}$. The warming trend was detected in all seasons but with the higher magnitude in spring and winter. Snow cover duration has decreased in Estonia by 3-4 days decade ${ }^{-1}$. Changes in precipitation are not clear and uniform due to their very high spatial and temporal variability. The most significant increase in precipitation was observed during the cold half-year, from November to March and also in June. A time series of specific runoff measured at 21 stations had significant seasonal changes during the study period. Winter values have increased by $0.4-0.9 \mathrm{~L} \mathrm{~s}^{-1} \mathrm{~km}^{-2} \mathrm{decade}^{-1}$, while stronger changes are typical for western Estonia and weaker changes for eastern Estonia. At the same time, specific runoff in April and May have notably decreased indicating the shift of the runoff maximum to the earlier time, i.e. from April to March. Air temperature, precipitation, snow cover duration and specific runoff of rivers are highly correlated in winter determined by the large-scale atmospheric circulation. Correlation coefficients between the Arctic Oscillation (AO) and North Atlantic Oscillation (NAO) indices reflecting the intensity of westerlies, and the studied variables were $0.5-0.8$. The main result of the analysis of regime shifts was the detection of coherent shifts for air temperature, snow cover duration and specific runoff in the late 1980s, mostly since the winter of 1988/1989, which are, in turn, synchronous with the shifts in winter circulation. For example, runoff abruptly increased in January, February and March but decreased in April. Regime shifts in annual specific runoff correspond to the alternation of wet and dry periods. A dry period started in 1964 or 1963, a wet period in 1978 and the next dry period at the beginning of the 21 st century.
\end{abstract}

\section{Introduction}

Different methods of trend analysis are usually applied for the detection of climate changes. For example, using regression analysis climate warming in the Baltic Sea region including Estonia is estimated to be faster than the increase in the global mean temperature (Jaagus, 2006; BACC, 2008, 2015). Annual mean air temperature has increased by $0.11 \mathrm{~K} \mathrm{decade}^{-1}$ in the northern part of the Baltic Sea basin, and by $0.08 \mathrm{~K}_{\text {decade }}-1$ in its southern part during $1871-$ 2011 (BACC, 2015). The most significant warming was observed in spring and winter. The most dramatic changes in the Baltic Sea region have taken place just during the last decades (Lehmann et al., 2011).

The North Atlantic Oscillation (NAO) strongly affects surface temperatures in the Northern Hemisphere with patterns often reported to be similar to the global warming trend (e.g. 
Hurrell, 1995; Rodwell et al., 1999). Also, several studies show the evidence for ongoing intensification of the global water cycle, including increasing river runoff (Labat et al., 2004; Huntington, 2006). However, it is known that trend analysis, especially of linear trends, has certain limitations. Linear regression analysis disregards the internal variability in the time series. At the same time, those internal alterations provide a lot of important information on climate changes.

In addition to linear trends, there could also be abrupt changes, i.e. jumps or breaks, which divide a time series into parts with different statistical properties, called regime shifts. Initially, the term regime shift was used in marine ecology and was inspired by changes in climate of the North Pacific (Kerr, 1992) and salmon production around 1977 (Mantua et al., 1997; Rodionov, 2004). This means a large, abrupt and persistent change in the structure and function of a (natural) system (Biggs et al., 2009). In oceanography and climatology, a regime shift is characterised by an abrupt transition from one quasi-steady climatic state to another, and its transition period is much shorter than the lengths of the individual periods of each climatic state. The semantics and the essence of regime shifts are described in detail by Overland et al. (2008). There are several concepts of the definition of regimes (Rodionov, 2005; Overland et al., 2008). Here we used only the concept of displacement, i.e. the inspection of time series over relatively short periods where there can be sequential multi-year intervals with mean values in each interval that are statistically different, relative to their withinregime variance.

As there are several definitions and methods to detect regime shifts, there are also numerous regime shifts in climate variables detected by different authors. For example, Swanson and Tsonis (2009) identified climatic regime shifts in global mean temperature in 1910-1920, 1938-1945, 1976-1981 and 2001-2002. A regime shift in the North Atlantic was observed in the 1920s and 1930s (Drinkwater, 2006). However, a number of studies have detected regime shifts in many parameters in late 1980s, especially since 1989. For example, analysing wintertime sea-surface temperatures over the Northern Hemisphere during the 20th century, six regime shifts were detected, one of them being in 1988/1989 (Yasunaka and Hanawa, 2002). An abrupt warming over the Northern Hemisphere in the late 1980s has been examined by many authors (Rodionov and Overland, 2005; Tsunoda et al., 2008; Lo and Hsu, 2010; Kim et al., 2015). Oceanographic, climatological and biological time series from the North Pacific and the Bering Sea revealed regime shifts in 1977, 1989 and 1998 (Overland et al., 2008). The shift of 1989 in that region was also analysed by Hare and Mantua (2000). Regime shifts in the late 1980s have also been detected in the Arctic sea-level pressure (Walsh et al., 1996), intensification of upper air polar vortex (Tanaka et al., 1996) and a decadal-scale atmospheric circulation (Watanabe and Nitta, 1999). This change is explained by a northward expansion of the Hadley cell, a poleward expansion and in- tensification of the Ferrel cell, and a collapse of the polar cell (Kim et al., 2015). A thorough analysis of the regime shifts in the 1980s and their global impact on the biosphere was conducted by Reid et al. (2016).

There is also much evidence of regime shifts in the North Atlantic and European region in late 1980s. For example, a regime shift on this period was reported from the Mediterranean Sea based on ecological, hydrological and climatic variables (Conversi et al., 2010). In a review article on regime shifts in marine ecosystems, many studies are referred to where the shift since 1989 in the North Atlantic was found (DeYoung et al., 2004). Using long time series of the winter Baltic climate index (WIBIX) based on monthly values of the first principal component of winter anomalies (JanuaryMarch) of the NAO index, sea-level anomalies at Landsort (Sweden) and maximum Baltic ice cover, Hagen and Feistel (2005) determined the alternation of two climate regimes over the Baltic Sea. The last period of mild winters started in 1988 (Hagen and Feistel, 2005). In marine ecosystems of the Baltic Sea a regime shift was observed in the late 1980s. Here, the phytoplankton biomass increased, the composition of phyto- and zooplankton communities changed conspicuously and the growing season was extended (Alheit et al., 2005; Möllmann et al., 2009; Dippner et al., 2012).

As the Baltic Sea is situated in the transition area of Atlantic marine and Eurasian continental climate systems and influenced by air masses from Arctic to subtropical origin, the climatic conditions here are characterised by high spatiotemporal variations (BACC, 2008; Rutgersson et al., 2014). Thus, the Baltic Sea region poses a great challenge for the detection of trends and regime shifts in the climatic, hydrological and ecological variables.

Estonia is located in the central part of the Baltic Sea region, at the eastern coast of the sea (Fig. 1). As in the whole of northern Europe, air temperature has increased in Estonia during the period of instrumental meteorological observations (Jaagus, 1998). The highest warming was detected during the second half of the 20th century, when statistically significant trends were detected for annual and spring mean temperature (Jaagus, 2006). Trend values for annual temperature were $0.2-0.3 \mathrm{~K} \mathrm{decade}^{-1}$, and for spring and winter temperature even $0.4-0.6 \mathrm{~K} \mathrm{decade}^{-1}$. In the majority of the studied stations, annual and winter precipitation has also increased significantly in Estonia. It has been demonstrated that these climatic changes have been closely related to changes in the large-scale atmospheric circulation or, more precisely, to the intensification of westerly circulation over the Atlantic/European sector in winter (Jaagus, 2006). It will be important to monitor whether these trends have also continued in the beginning of the 21 st century.

Several studies have shown regime shifts in climate variables over the Gulf of Finland and in Estonia. An increase in zonal circulation starting in 1987 was detected in February (Keevallik and Soomere, 2008). A similar shift at the end of the 1980s was found in the time series of cumulative wind 


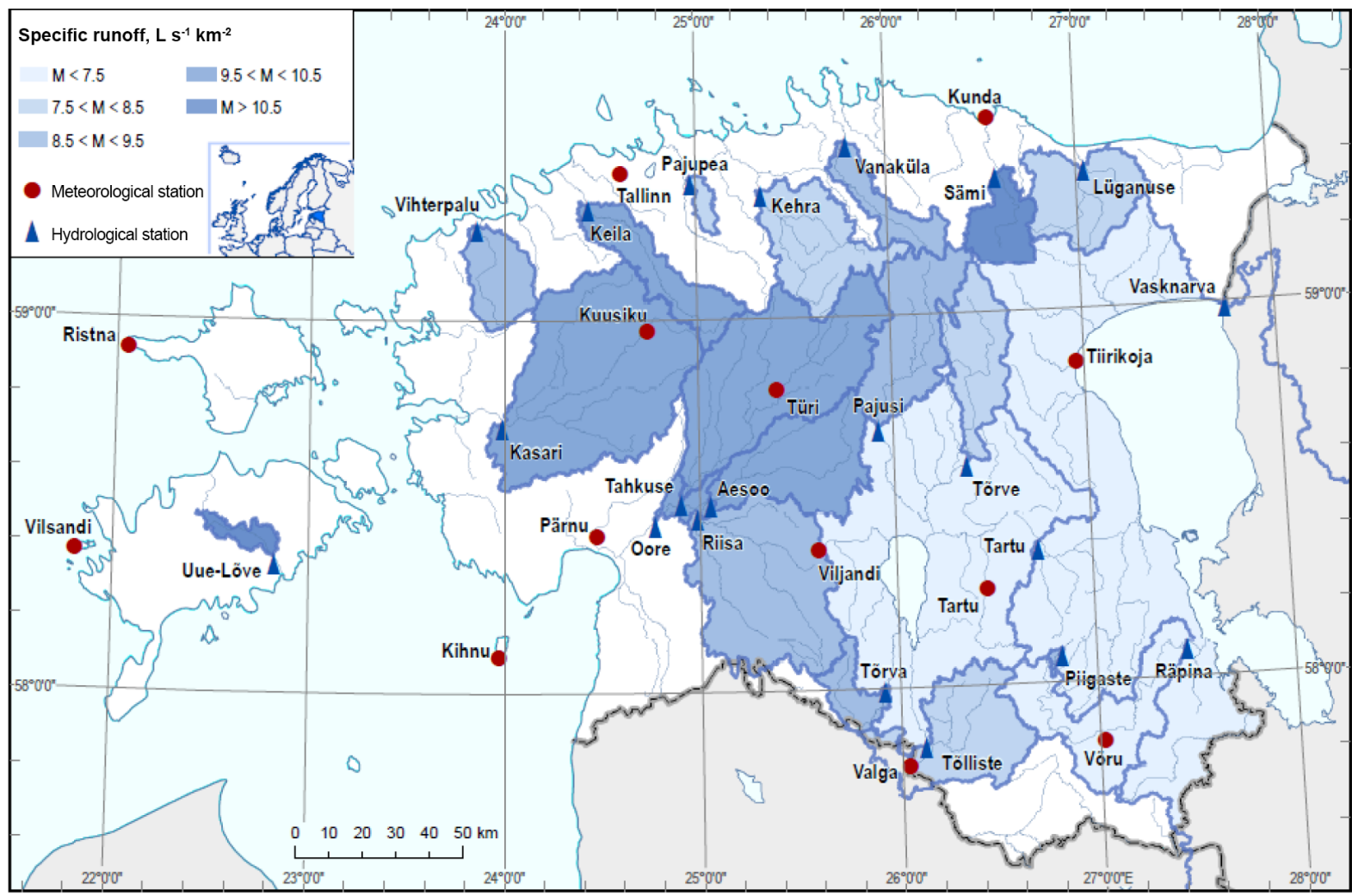

Figure 1. Location map of Estonia with meteorological and hydrological stations, as well as annual mean specific runoff of studied river basins.

stress calculated for December-January using data from Utö (Elken et al., 2014). Dynamics of wave properties of the Baltic Sea were analysed by Soomere and Räämet (2014), who simulated these using the WAM model. These dynamics were related to annual mean components of air flow of the adjusted geostrophic wind. A shift in simultaneity in annual mean wave length between eight stations in the eastern coast of the Baltic Sea was detected starting in 1988 (Soomere et al., 2015). This was related to the observed shifts in the annual mean zonal and meridional components of airflow of the adjusted geostrophic wind. During the period 1981-2010 an upward shift in average airflow speed over the Gulf of Finland area in January was detected in 1988 and a downward return shift in 1994 (Keevallik and Soomere, 2014). Based on the data of two stations (Vilsandi and Tiirikoja, Estonia), an abrupt increase was observed in the zonal component of average air flow from January to March, in air temperature for January and February, and in precipitation for February (Keevallik, 2011). However, the precipitation regime in the eastern Baltic region can be characterised by a very high spatial and temporal variability and thus there are few reliable trends in time series of precipitation (Jaagus et al., 2010, 2016).

Long-term fluctuations in climatic parameters are reflected in the dynamics of river runoff that has relatively short residence time. River runoff in Estonia is characterised by a significant seasonal and interannual variability. It is mostly caused by precipitation variations and snow conditions during the winter season and the melting period in spring. The runoff regime is also affected by hydrographical and hydrogeological characteristics, in which we can find relatively large differences in Estonian catchment areas. Variability and trends in river discharge in the Baltic countries have been analysed by many authors (Järvet, 1998; Reihan et al., 2006, 2007, 2012; Kriaučiuniene et al., 2012). These authors found that increasing trends in river runoff were characteristic only in the winter season during the 20th century. At the same time, runoff fluctuations with a period of ca. 30 years are dominant in the time series for Estonia. Using the water balance model WATBAL, changes in river runoff in Estonia were modelled for the case of continuous climate warming (Jaagus et al., 1998). The results indicated an increase in runoff in winter and decrease in spring, which could lead to drought conditions in the end of spring and beginning of summer.

The objective of this study is a joint analysis of changes, i.e. trends and regime shifts in main climatic (temperature, precipitation, snow cover duration) and hydrologic (river runoff) variables and in indices of large-scale atmospheric circulation to detect coherent changes. The study period 1951-2015 was chosen as it is the period when the highest 
number of stations with continuous time series is available in Estonia. The main idea and novelty of this study in comparison with the previous ones was to realise an integrated analysis of trends and regime shifts in time series of many inter-related and indicative variables of the climate system starting from the indices of the large-scale atmospheric circulation and ending with specific runoff of rivers.

\section{Data and methods}

Annual, seasonal and monthly mean air temperature and precipitation at 12 stations in Estonia (Fig. 1) for 1951-2015 have been used for the analysis. No significant relocations of the measuring sites have taken place at these stations, with the exception of two stations. In 1980, the Tallinn station was moved from Ülemiste (airport) to Harku, ca. $12 \mathrm{~km}$ to the west. Thereby, the local placement on the limestone plateau several kilometres from the sea coast remained nearly the same. In 1997 the Tartu station was moved from Ülenurme to Tõravere, $15 \mathrm{~km}$ to the south-west. Analysis of time series did not reveal inhomogeneities due to these displacements (Sits and Post, 2006; Keevallik and Vint, 2012). Adding of the wetting correction to the measured precipitation at all stations since 1966 was the only important source of inhomogeneity that is not eliminated from the time series. The wetting correction takes about $10 \%$ of monthly precipitation, which is difficult to detect. In addition, time series of snow cover duration at five stations are analysed to better describe winter weather conditions.

For generalisation of the results, time series of spatial mean temperature and precipitation were also analysed. Mean temperature for Estonia was calculated by averaging the values of the 12 stations. Spatial mean precipitation for Estonia was calculated by averaging the gridded values, which were interpolated using all available precipitation data (Jaagus, 1992).

We used specific runoff of rivers (in litres per second per square kilometre) because it allows comparing observed data from river basins of different size and assessing results of statistical analyses. Monthly, seasonal and annual specific runoff values in the period 1951-2015 have been used from all 21 stations with various catchment areas, hydrological and hydrogeological conditions where the long series of measurements is available in Estonia (Fig. 1). Seasons were defined by 3 months as usual in climatological studies: spring (MAM), summer (JJA), autumn (SON) and winter (DJF). Hydrological parameters of these river basins are presented in Table 1.

Large-scale atmospheric circulation is an important factor influencing on local weather conditions. In this study, changes in circulation are analysed using annual, seasonal and monthly values of the Arctic Oscillation (AO) index, several North Atlantic Oscillation indices and teleconnection indices provided by the NOAA Climate Prediction Cen- ter. The AO index reflects the intensity of the circumpolar air vortex (Thompson and Wallace, 1998). North Atlantic Oscillation (NAO) describes the intensity of westerlies over the Atlantic/European sector (Hurrell, 1995). We have used several NAO indices: NAOG using sea-level pressure (SLP) data from Gibraltar and Stykkishólmur/Reykjavík (Jones et al., 1997), NAOL using data from Lisbon and Reykjavík/Stykkishólmur (Hurrell, 1995) and NAOPC, which are calculated using principal component analysis (PCA) of SLP fields (Hurrell and Deser, 2009).

Teleconnection patterns have been defined as a result of PCA of SLP fields over the Northern Hemisphere (Barnston and Livezey, 1987). Here we use only these teleconnection patterns, which represent atmospheric circulation over the Baltic Sea region. Monthly values are presented and updated by the NOAA Climate Prediction Centre (http://www.cpc.ncep.noaa.gov/data/teledoc/telecontents. shtml). The North Atlantic Oscillation (NAOT), East Atlantic (EA) and Polar/Eurasia (POL) patterns describe mostly zonal circulation, while the East Atlantic/West Russia (EAWR) and Scandinavia (SCA) patterns describe the meridional circulation.

The Mann-Kendall test is used to detect trends in time series (Mann, 1945; Kendall, 1975). The reason for selecting the test is that the consistency with normal (Gaussian) distribution in the case of climatic and hydrological parameters is usually not fulfilled. The trend slope is calculated using Sen's method (Sen, 1968). Trends are expressed in changes per decade. They are considered statistically significant at the $p<0.05$ level.

Correlation coefficients are used for expressing the strength and direction of statistical relationship between time series of different climatic and hydrological variables. As the length of the time series in this case is 65 years, then the critical value of statistical significance at the $p<0.05$ level is $r=0.245$ and at the 0.01 level $r=0.318$. All correlation coefficients presented in this study are statistically significant at least at the $p<0.05$ level.

The STARS (sequential $t$-test analysis of regime shifts) method, known also as the Rodionov test (Rodionov, 2004; Rodionov and Overland, 2005), was used for the detection of regime shifts in time series. The identification of a regime shift is based on calculating the regime shift index (RSI), which represents a cumulative sum of normalised deviations of the time-series values from the hypothetical mean level for the new regime. This is the level for which the difference with the mean level for the previous regime is statistically significant according to Student's $t$ test. If the RSI remains positive during a time period equal to the cut-off length, a shift is declared (Rodionov, 2004). Here, we used an Excel macro developed by S. N. Rodionov, which is downloadable from the Bering Sea Climate website http://www.beringclimate.noaa. gov/regimes/. As in the case of many statistical methods, the STARS method has no strict rules for the selection of input parameters. The choice depends on the purpose of the study. 
Table 1. The list of hydrological stations used in this study, their catchment areas and characteristics of annual mean specific runoff $\left(\mathrm{L} \mathrm{s}^{-1} \mathrm{~km}^{-2}\right)$.

\begin{tabular}{llrrrrr}
\hline River & Station & Area, $\mathrm{km}^{2}$ & Annual mean & St. deviation & Annual maximum & Annual minimum \\
\hline Narva & Vasknarva & 47800 & 6.85 & 1.83 & $10.88(1990)$ & $3.37(1973)$ \\
Emajõgi & Tartu & 7840 & 7.44 & 1.89 & $11.32(1990)$ & $3.71(1996)$ \\
Pedja & Tõrve & 776 & 7.85 & 2.19 & $13.25(1981)$ & $3.92(1996)$ \\
Põltsamaa & Pajusi & 1030 & 9.23 & 2.49 & $15.03(1962)$ & $4.38(2006)$ \\
Piigaste & Piigaste & 11.5 & 8.94 & 2.71 & $16.04(1978)$ & $4.01(1965)$ \\
Võhandu & Räpina & 1130 & 7.28 & 1.73 & $11.43(1990)$ & $4.17(1996)$ \\
Väike-Emajõgi & Tõlliste & 1050 & 7.90 & 1.97 & $14.31(1978)$ & $4.28(1996)$ \\
Öhne & Tõrva & 269 & 8.87 & 2.50 & $18.41(1978)$ & $4.74(1965)$ \\
Halliste & Riisa & 1880 & 9.27 & 2.66 & $16.50(1978)$ & $4.13(1996)$ \\
Navesti & Aesoo & 1008 & 9.13 & 2.77 & $17.22(1981)$ & $4.06(1996)$ \\
Pärnu & Tahkuse & 2080 & 9.92 & 2.81 & $18.16(1981)$ & $5.40(1964)$ \\
Pärnu & Oore & 5160 & 9.62 & 2.76 & $17.05(1981)$ & $4.95(1996)$ \\
Lõve & Uue-Lõve & 134 & 10.65 & 3.34 & $19.52(2012)$ & $5.40(1976)$ \\
Kasari & Kasari & 2640 & 9.62 & 2.79 & $15.74(2012)$ & $5.02(2003)$ \\
Vihterpalu & Vihterpalu & 474 & 9.29 & 2.84 & $19.19(2012)$ & $3.59(2003)$ \\
Keila & Keila & 635 & 9.78 & 3.02 & $16.83(2012)$ & $4.77(2006)$ \\
Leivajõgi & Pajupea & 83 & 8.12 & 2.54 & $14.26(1981)$ & $3.63(2006)$ \\
Jägala & Kehra & 903 & 8.23 & 2.41 & $15.86(1981)$ & $3.37(1996)$ \\
Valgejõgi & Vanaküla & 404 & 8.65 & 2.34 & $15.51(1981)$ & $4.12(2006)$ \\
Kunda & Sämi & 406 & 10.77 & 2.66 & $17.44(1962)$ & $5.45(2006)$ \\
Purtse & Lüganuse & 784 & 8.35 & 2.65 & $15.66(1981)$ & $3.08(1964)$ \\
\hline
\end{tabular}

For example, if there is a need to detect short-term variations in the time series, then loose parameters can be used - a high Huber's weight parameter (HWP), short cut-off length $(l)$ and low significance level of the $t$ test $(p)$. Our task was to study general changes in atmospheric circulation and climatic and hydrological variables. Therefore we used a relatively conservative set of input parameters: $l=10$ years, $p=0.05$ and HWP $=1$. HWP determines the weight of outliers in the calculation of mean values before and after the shift. No prewhitening methods were used.

The output of the test is a year when a regime shift occurs (or years of shifts if the time series contains multiple statistically significant shifts), i.e. the first year of the new level. The shift is expressed in RSI, which represents a relative magnitude of the shift. The higher the value of RSI the more abrupt and statistically reliable the shift is. However, RSI does not present the shift in terms, for example, of centigrade or millimetres of precipitation. Thus, one output of the test is the difference between the weighted means, which is used as a shift value for describing the magnitude of the shift.

One of the peculiarities of the STARS method is that it tends to find regime shifts in the end of time series. This characteristic of the method has been considered as an advantage that allows processing "data in real time, signalling the emergence of a potential shift and measuring changing confidence in the evidence for a shift as new data arrive" (Rodionov and Overland, 2005). Also, from a formal point of view, those RSI shifts are statistically reliable. However, it is understandable that in reality those shifts in the last years are meaningless and do not represent any substantial changes. Thus, we have ignored shifts that occurred in last 5 years of the analysed time series.

\section{Results}

\subsection{Indices of large-scale atmospheric circulation}

As large-scale atmospheric circulation has close relationships with air temperature and precipitation in Estonia (Jaagus, 2006), circulation indices were analysed as the main factors inducing climate variability. Statistically significant trends in the indices of large-scale atmospheric circulation are comparatively rare (Table 2 ). The most remarkable feature is the significant increase in different NAO indices in winter. It means that negative NAO indices have become to occur less and positive anomalies more during the study period indicating the tendency of intensification of westerly circulation over the Atlantic/European sector. Increasing trends in the NAO indices were observed in January, February and March, while decreasing trends were found in June and October. The AO index has a statistically significant increasing trend only in March, November, spring and annually. It is interesting that the EA index can be characterised by an increasing tendency throughout a year. The EAWR, SCA and POL teleconnection indices have some, mostly decreasing, trends in single months (Table 2).

The AO index and NAO indices for winter demonstrate a statistically significant positive regime shift since the winter 
Table 2. Trend values of monthly, annual and seasonal indices of large-scale atmospheric circulation. Statistically significant trends on $p<0.05$ are in bold.

\begin{tabular}{lrrrrrrrrr}
\hline & AO & NAOL & NAOG & NAOPC & NAOT & EA & EAWR & SCA & POL \\
\hline Jan & 1.12 & $\mathbf{1 . 9 5}$ & 1.13 & $\mathbf{1 . 4 0}$ & $\mathbf{1 . 0 2}$ & $\mathbf{2 . 0 3}$ & -0.04 & 0.09 & $\mathbf{- 1 . 1 9}$ \\
Feb & 1.16 & $\mathbf{1 . 8 5}$ & 1.25 & $\mathbf{1 . 3 6}$ & $\mathbf{1 . 2 3}$ & 0.86 & 0.41 & 0.37 & -0.99 \\
Mar & $\mathbf{1 . 1 8}$ & $\mathbf{1 . 8 2}$ & 1.05 & $\mathbf{1 . 6 3}$ & $\mathbf{1 . 5 8}$ & 1.04 & -0.22 & -0.24 & $\mathbf{- 1 . 0 9}$ \\
Apr & 0.44 & -0.11 & -0.41 & 0.26 & 0.46 & $\mathbf{1 . 4 2}$ & 0.61 & -0.75 & -0.20 \\
May & 0.61 & 0.62 & 0.02 & 0.40 & -0.21 & 0.90 & -0.68 & -0.46 & -0.08 \\
Jun & -0.11 & $-\mathbf{1 . 6 0}$ & $-\mathbf{1 . 8 4}$ & -0.49 & -0.75 & 0.53 & $-\mathbf{1 . 5 2}$ & $-\mathbf{1 . 0 0}$ & 0.35 \\
Jul & -0.18 & -0.76 & -1.09 & -0.40 & -0.66 & $\mathbf{1 . 6 5}$ & -0.42 & 0.26 & 0.65 \\
Aug & 0.24 & 0.29 & -0.48 & -0.07 & -0.03 & $\mathbf{1 . 7 6}$ & -0.96 & -0.77 & $\mathbf{1 . 1 3}$ \\
Sep & 0.32 & -0.54 & $-\mathbf{1 . 8 6}$ & -0.06 & 0.10 & 0.59 & -0.85 & 0.09 & 0.23 \\
Oct & -0.50 & -1.47 & $-\mathbf{1 . 6 9}$ & $-\mathbf{1 . 1 6}$ & $-\mathbf{1 . 5 2}$ & $\mathbf{1 . 3 9}$ & $-\mathbf{0 . 8 5}$ & -0.66 & -0.48 \\
Nov & $\mathbf{1 . 1 0}$ & 1.08 & 0.14 & 0.72 & 0.59 & $\mathbf{1 . 6 2}$ & 0.17 & -0.56 & -0.11 \\
Dec & 0.53 & -0.14 & 0.81 & 0.57 & 0.84 & $\mathbf{1 . 8 1}$ & -0.11 & -0.36 & $\mathbf{- 0 . 9 5}$ \\
\hline Year & $\mathbf{0 . 4 3}$ & 0.42 & -0.26 & 0.38 & 0.25 & $\mathbf{1 . 1 8}$ & -0.35 & $-\mathbf{0 . 3 2}$ & $-\mathbf{0 . 3 5}$ \\
\hline Spring & $\mathbf{0 . 6 9}$ & 0.55 & 0.06 & $\mathbf{0 . 7 5}$ & $\mathbf{0 . 6 4}$ & $\mathbf{0 . 9 7}$ & -0.11 & $-\mathbf{0 . 5 1}$ & $-\mathbf{0 . 7 4}$ \\
Summer & 0.00 & -0.60 & $-\mathbf{1 . 2 5}$ & -0.27 & -0.49 & $\mathbf{1 . 3 3}$ & $-\mathbf{0 . 9 1}$ & -0.39 & 0.58 \\
Autumn & 0.27 & -0.25 & $-\mathbf{0 . 9 1}$ & -0.19 & -0.24 & $\mathbf{1 . 0 4}$ & $-\mathbf{0 . 5 6}$ & -0.39 & 0.12 \\
Winter & 0.79 & $\mathbf{1 . 1 3}$ & 0.84 & $\mathbf{1 . 1 1}$ & $\mathbf{0 . 9 9}$ & $\mathbf{1 . 5 0}$ & 0.06 & 0.02 & $-\mathbf{1 . 0 0}$ \\
\hline
\end{tabular}

Table 3. Years of statistically significant upward (+) and downward (-) shifts in time series of the circulation indices from different months and seasons.

\begin{tabular}{|c|c|c|c|c|c|c|c|c|c|c|c|c|}
\hline \multirow{13}{*}{$\begin{array}{l}\text { Jan } \\
\text { Feb } \\
\text { Mar } \\
\text { Apr } \\
\text { May } \\
\text { Jun } \\
\text { Jul } \\
\text { Aug } \\
\text { Sep } \\
\text { Oct } \\
\text { Nov } \\
\text { Dec }\end{array}$} & \multicolumn{2}{|c|}{$\mathrm{AO}$} & \multicolumn{2}{|c|}{ NAOL } & \multicolumn{2}{|c|}{ NAOG } & \multicolumn{2}{|c|}{ NAOPC } & \multicolumn{2}{|c|}{ NAOT } & \multicolumn{2}{|c|}{ EA } \\
\hline & + & - & $\begin{array}{r}+ \\
1983\end{array}$ & - & + & - & + & - & $\begin{array}{r}+ \\
1983\end{array}$ & $\begin{array}{r}- \\
1963\end{array}$ & $\begin{array}{r}+ \\
1970\end{array}$ & - \\
\hline & 1989 & & 1989 & 2004 & & & 1989 & 2004 & 1988 & 2004 & & \\
\hline & & & & & & & 1989 & & 1982 & & & \\
\hline & & & & & 1990 & 1971 & & & & & 1983 & \\
\hline & 1961 & & & & & & & & & & & \\
\hline & & 2009 & & & & 2007 & & 2007 & 1964 & 2007 & & \\
\hline & & & & 1962 & & & & & & 2008 & 1998 & \\
\hline & 1991 & 2002 & & & & & & & & & 2009 & \\
\hline & 2003 & & & & 2003 & 1993 & & & & & & \\
\hline & & & & 1965 & & & & & & & 1980 & \\
\hline & & & & & & & & & & & & \\
\hline & & & & & & & & & & & 1977 & \\
\hline Year & 1989 & & & & & & 1989 & & & & 1977 & \\
\hline Spring & & & & & & & 1989 & & 1986 & 2007 & 2001 & \\
\hline Summer & & 2009 & & & & 2007 & & 2007 & & 2007 & 1998 & \\
\hline Autumn & & & & 1965 & & & & & & & & 1988 \\
\hline Winter & 1989 & & & & 1989 & & 1989 & & 1988 & & 1987 & \\
\hline
\end{tabular}

of 1988/1989 (Table 3), reflecting an abrupt intensification of the westerly circulation. The upward shift year 1989 was detected for the following indices: AO - February, winter and annual time series; NAOL - February; NAOG - winter; NAOPC - February, March, winter, spring and annually; and NAOT - February, winter. In the case of the NAOT the shift year was 1988. Return shifts for the NAO indices appeared mostly in February since 2004. A negative regime shift was found for the summer NAO index starting in 2007. The EA teleconnection index has significant upward regime shifts in many months and in all seasons except autumn (Table 3) corresponding to their increasing trends (Table 2) but at different years: from 1970 to 2009. Other teleconnection indices had few regime shifts (not shown in Table 3). 
Table 4. Trend values, shift years and shift values of spatially averaged monthly, annual and seasonal mean air temperature and precipitation in Estonia during 1951-2015. Statistically significant trends on $p<0.05$ are in bold. A significant downward regime shift for temperature was detected only in January from 1966 by $-2.5 \mathrm{~K}$.

\begin{tabular}{|c|c|c|c|c|c|c|c|c|}
\hline & \multicolumn{3}{|c|}{ Temperature } & \multicolumn{5}{|c|}{ Precipitation } \\
\hline & $\begin{array}{r}\text { Trend } \\
\left(\mathrm{K} \text { decade }^{-1}\right)\end{array}$ & $\begin{array}{r}\text { Upward } \\
\text { shift year }\end{array}$ & $\begin{array}{r}\text { Shift } \\
\text { value }(\mathrm{K})\end{array}$ & $\begin{array}{r}\text { Trend } \\
\left(\mathrm{mm} \mathrm{decade}^{-1}\right)\end{array}$ & $\begin{array}{l}\text { Upward } \\
\text { shift year }\end{array}$ & $\begin{array}{r}\text { Shift } \\
\text { value }(\mathrm{mm})\end{array}$ & $\begin{array}{r}\text { Downward } \\
\text { shift year }\end{array}$ & $\begin{array}{r}\text { Shift } \\
\text { value }(\mathrm{mm})\end{array}$ \\
\hline Jan & 0.37 & 1988 & 4.0 & 2.0 & & & & \\
\hline Feb & 0.54 & 1989 & 2.3 & 1.0 & 1995 & 24.0 & 2003 & -21.7 \\
\hline Mar & 0.62 & 1966 & 3.4 & 1.3 & 1988 & 23.4 & 1996 & -18.6 \\
\hline Apr & 0.43 & 1989 & 1.9 & -0.3 & & & & \\
\hline May & 0.34 & & & 0.7 & & & & \\
\hline Jun & 0.06 & & & 3.0 & & & & \\
\hline Jul & 0.35 & 2001 & 2.2 & -0.5 & & & & \\
\hline Aug & 0.27 & 2002 & 1.4 & 1.1 & & & & \\
\hline Sep & 0.27 & 2004 & 1.6 & -1.7 & & & 1998 & -18.9 \\
\hline Oct & 0.05 & & & 1.6 & & & & \\
\hline Nov & 0.28 & & & 1.9 & 1969 & 19.2 & & \\
\hline Dec & 0.36 & & & 1.3 & 2009 & 20.2 & & \\
\hline Year & 0.33 & 1988 & 1.4 & 12.7 & 1977 & 85.5 & & \\
\hline Spring & 0.48 & 1983 & 1.5 & 1.1 & 1966 & 19.2 & & \\
\hline Summer & 0.25 & 1999 & 1.2 & -0.4 & & & & \\
\hline Autumn & 0.26 & 2005 & 1.6 & 3.3 & 1977 & 32.1 & & \\
\hline Winter & 0.39 & 1989 & 2.3 & 4.7 & & & & \\
\hline
\end{tabular}

\subsection{Surface air temperature}

Results of the Mann-Kendall test show a large warming in Estonia during the period 1951-2015. Annual mean air temperature has significantly increased at the studied stations by $2.0-2.5 \mathrm{~K}$ for the whole period or by $0.3-0.4 \mathrm{~K} \mathrm{decade}^{-1}$. Statistically significant warming has also been detected for all seasons, while the trend values are higher than the annual mean in winter and spring and lower in summer and autumn. Among single months, statistically significant trends during the study period were detected in March, April, May, July, August, September and November (Table 4). No trends were observed in June and October. Notable warming in January, February and December was mostly insignificant due to a very high temporal variability in air temperature in winter.

Upward regime shifts are typical for air temperature (Table 4). Winter mean temperature has abruptly increased since $1988 / 1989$ by $1.9-2.7 \mathrm{~K}$ at different stations. The highest shift value was recorded in Tartu. Generally, the trends and regime shifts at the coastal stations in the western Estonia are weaker than in the inland stations of eastern Estonia. For example, the changes by trend in annual, winter and spring temperature during the 65 years were in coastal stations (Vilsandi: 2.2, 2.4 and 3.0; Ristna: 2.0, 2.1 and 2.5; Tallinn: 1.9, 2.4 and 3.2, respectively) and in inland stations of eastern Estonia (Võru: 2.4, 2.4 and 3.4; Tartu: 2.5, 2.9 and 3.7; Tiirikoja: $2.3,3.1$ and $3.7 \mathrm{~K}$, respectively). The values of regime shift in winter mean temperature since 1989 were the following: Vilsandi: 1.9; Ristna: 1.9; Tallinn: 2.2; Võru: 2.4; Tartu: 2.7; and Tiirikoja $2.7 \mathrm{~K}$.

A similar upward shift of even higher magnitude was found for monthly mean temperature in February, while some stations in southern Estonia had a downward shift starting in 2005. Stations in the continental part of Estonia had a downward shift of monthly mean temperature in January by $2.3-2.7 \mathrm{~K}$ starting in 1966 following the upward shift by 4.1-4.7 K from 1988. Statistically significant regime shifts in March and April temperature were found in two different years. In March, an upward shift by $3.2-3.9 \mathrm{~K}$ was revealed starting 1966 in the eastern half of the country and by $1.9-2.3 \mathrm{~K}$ from 1989 in the coastal region. In April, the shift to higher temperature by $1.5-2.1 \mathrm{~K}$ occurred in 1989 in the southern regions and the western coast, while in northern Estonia it happened starting in 1999 by $1.7-1.9 \mathrm{~K}$. The time series of spatial mean temperature in Estonia has a shift in March starting in 1966 and in April from 1989 (Table 4).

Regime shifts in air temperature for the warm half-year were detected more than 10 years later than for the cold half-year. Mean temperature in July had a jump by 2.0$2.4 \mathrm{~K}$ starting in 2001 (1999 in the island stations Vilsandi and Kihnu), in August the shift began in 2002 (1996 in Vilsandi and Kihnu) by $1.3-1.7 \mathrm{~K}$, and in September it began in 2004 by $1.5-1.7 \mathrm{~K}$. Mean temperature in spring has upward regime shifts in different years - starting in 1966, 1982 and 1989. Summer temperature shifted beginning in 1999, 2001 or 2010 at different stations and autumn temperature shifted 
Table 5. Trend values, years of regime shifts and corresponding shift values of snow cover duration. Statistically significant trends at $p<0.05$ are in bold.

\begin{tabular}{lrrr}
\hline Station & Trend values & Shift years & Shift values \\
\hline Pärnu & $\mathbf{- 4 . 0}$ & 1989 & -16.2 \\
Tallinn & $\mathbf{- 3 . 6}$ & 1989 & -16.6 \\
Tartu & -3.4 & 1989 & -20.2 \\
Vilsandi & -3.0 & 1989,2010 & $-31.9,32.4$ \\
Võru & -3.3 & 1989 & -16.8 \\
\hline
\end{tabular}

from 2005 onwards. Annual mean temperature had a statistically significant increase by $1.2-1.5 \mathrm{~K}$ in 1988 (or 1989).

Interannual fluctuations in time series of air temperature are statistically related to the variations in the indices of large-scale atmospheric circulation. The indices describing the intensity of westerly circulation (AO and NAO indices) are highly correlated with winter temperature. The correlation coefficient is usually $0.6-0.7$ or even higher. For example, correlations between winter mean temperature in Tartu and Ristna with the AO index in winter were 0.710 and 0.755 , and with NAOPC being 0.765 and 0.800 , respectively. Higher correlation was clearly seen in the coastal zone.

\subsection{Snow cover duration}

The warming in winter is closely related to the decrease in snow cover duration. The trend values were 34 days decade ${ }^{-1}$ in the five stations in Estonia (Table 5). The change was statistically significant at the $p<0.05$ level only at two stations. The low significance can be explained by a very high year-to-year variability in snow cover duration.

Time series of snow cover duration at all studied stations in the continental part of Estonia have a statistically significant negative shift by 16-20 days since the winter of 1988/89. An exception was detected in Vilsandi, which is located on the westernmost island under the direct influence of the Baltic Sea. A downward shift in snow cover duration by 31.9 days was observed in Vilsandi starting in 1988/1989, followed by an upward shift by 32.4 days detected beginning in 2009/2010.

Correlation between winter mean temperature and snow cover duration is lower $(r=-0.65$ to -0.75$)$ in the inland regions of Estonia and much higher in the coast of the Baltic Sea $(r=-0.88$ in Vilsandi). Similar spatial differences appear in correlation coefficients between snow cover duration and indices describing the intensity of westerly circulation ( $\mathrm{AO}, \mathrm{NAO}$ indices) in winter. Their values are between -0.5 and -0.7 .

\subsection{Precipitation}

Precipitation has even higher spatial and temporal variability than snow cover duration. Generally, correlations be- tween precipitation and other climatic parameters are comparatively weaker. Trend values for stations are quite different. There are no months or seasons when a statistically significant trend was observed in all stations. Increasing trends in monthly precipitation up to $5 \mathrm{~mm} \mathrm{decade}^{-1}$ were detected during the cold half-year (from November to March) and also in June (Table 4). The winter season has received significantly more precipitation, with the exception of Vilsandi. The majority of stations have also experienced a significant increase in annual precipitation by $15-30 \mathrm{~mm}$ decade $^{-1}$. Mostly no changes have been observed during the warm half-year (except June). An insignificant decrease could be noticed at some stations in April, July and September. Generally, there is no correlation between air temperature and precipitation in Estonia, but a weak positive correlation $(r=0.30-0.35)$ could be found in winter and a negative correlation of the same magnitude appears in May, June and August.

Due to the extremely high temporal variability, regime shifts in time series of precipitation are not so clearly expressed as in the case of temperature (Table 4). Several significant shifts up and down have been detected, which express, primarily, multi-annual fluctuations of precipitation and less abrupt climatic changes. Upward shifts by more than even $100 \mathrm{~mm}$ for annual precipitation were detected in many stations during 1977-1986. These shifts reflect the start of the period of higher precipitation starting in 1977. Similar shifts for winter precipitation were observed later, starting with $1980 / 1981$ and $1981 / 1982$ in three stations and ending with 1988/1989 and 1989/1990 in 4 of 12 stations. Positive regime shifts for monthly precipitation were revealed in all stations in the 1980s during the cold season from November to March. In many cases they were followed by return shifts in 2003 (February) and 1996 (March). Downward shifts in September precipitation were detected in many stations mostly beginning in 1998. Significant upward shifts since 1966 in spring (seven stations) and autumn precipitation (two stations) can be explained by the added wetting correction to every measured precipitation event.

\subsection{Specific runoff of rivers}

The trend analysis of specific runoff of rivers demonstrated mostly an increase in annual values, while a statistically significant trend was detected only in five stations (Table 6). At the same time, increasing trends were revealed at all stations (except Vasknarva, which is naturally regulated by Lake Peipsi) in the winter season and in the first 3 months of the year (Table 6). Trend values of specific runoff at single stations were quite different but mostly between 0.4 and $0.9 \mathrm{~L} \mathrm{~s}^{-1} \mathrm{~km}^{-2} \mathrm{decade}^{-1}$, while lower values are obtained from eastern Estonia and higher values from western Estonia. The time series of winter runoff in the Emajõgi River measured in Tartu describes most generally the interannual variations because its catchment area encompasses 
Table 6. Trend values, years of regime shifts and corresponding shift values of annual mean specific runoff. Statistically significant trends on $p<0.05$ are in bold.

\begin{tabular}{lrrr}
\hline Station & Trend values & Shift years & Shift values \\
\hline Vasknarva & 0.05 & $1964,1978,2000$ & $-2.70,3.43,-1.46$ \\
Tartu & $\mathbf{0 . 1 9}$ & 1964,1978 & $-2.10,2.85$ \\
Tõrve & 0.07 & 1963 & -0.86 \\
Pajusi & 0.00 & 1964 & -1.49 \\
Piigaste & 0.17 & 1963,1978 & $-3.53,3.90$ \\
Räpina & 0.10 & 1964,1978 & $-2.00,2.64$ \\
Tõlliste & $\mathbf{0 . 1 6}$ & 1964,1981 & $-1.88,2.35$ \\
Tõrva & $\mathbf{0 . 3 4}$ & 1981 & 2.61 \\
Riisa & $\mathbf{0 . 2 6}$ & & \\
Aesoo & 0.20 & 1981 & 2.82 \\
Tahkuse & 0.23 & 1981 & 3.71 \\
Oore & 0.22 & 1978 & -1.90 \\
Uue-Lõve & $\mathbf{0 . 4 7}$ & 1984,1996 & \\
Kasari & 0.21 & & \\
Vihterpalu & 0.16 & 1984 & \\
Keila & 0.22 & & \\
Pajupea & 0.06 & & \\
Kehra & 0.11 & & \\
Vanaküla & 0.10 & & \\
Sämi & 0,15 & & \\
Lüganuse & 0,11 & & \\
\hline
\end{tabular}

$17 \%$ of the total territory of Estonia. The highest increase was detected in Uue-Lõve River basin on Saaremaa Island, where the trend value of winter mean specific runoff was $1.1 \mathrm{~L} \mathrm{~s}^{-1} \mathrm{~km}^{-2}$ decade $^{-1}$. Vasknarva station is an exception due to its location in the outflow from Lake Peipsi to the Narva River, which has a runoff regime very different from other rivers. It has a large area of river basin buffered by the large lake. A significant increasing trend revealed there only in February and March.

During the other months few significant trends were detected. In southern Estonia (Õhne, Väike-Emajõgi and Piigaste rivers) runoff also increased in June and in Võhandu river (Räpina station) in July. They are related to the increase in precipitation in June. Mostly negative changes are typical for spring. In April, which is the most common month for spring flood to occur, the specific runoff has decreased by up to $1 \mathrm{~L} \mathrm{~s}^{-1} \mathrm{~km}^{-2}$ decade $^{-1}$, but this trend was statistically significant only for the Õhne and Kasari rivers. The decrease in May was significant in central and northern Estonia, in 8 of 21 stations. It is related to the shift of the spring runoff maximum caused by snowmelt to the earlier time, i.e. to March. Annual mean specific runoff has significantly increased in some rivers of southern Estonia (in the Emajõgi, Väike-Emajõgi, Õhne and Halliste rivers) by $0.2-$ $0.3 \mathrm{~L} \mathrm{~s}^{-1} \mathrm{~km}^{2-}$ decade ${ }^{-1}$, and in the Uue-Lõve River in the west Estonian archipelago by $0.47 \mathrm{~L} \mathrm{~s}^{-1} \mathrm{~km}^{-2}$ decade $^{-1}$.

Relationship between climatic variables and runoff in Estonia is well exposed, particularly in winter. Higher temperature, precipitation and lower snow cover duration in winter are related to higher winter runoff. Correlations between temperature and runoff in January, February and March are up to 0.7 ; those between precipitation and runoff are up to 0.6 ; and those between snow cover duration and runoff are up to -0.6. At the same time, correlation between snow cover duration and specific runoff in April is strongly positive $(r=0.5-0.6)$.

Time series of annual mean runoff describe long-term alternation of wet and dry periods in Estonia (Table 6). A downward shift in 1963 or 1964 followed by an upward shift starting in 1978 or 1981 mark the dry period in the middle of the whole study period. Some stations and some months show decreasing runoff again in the beginning of the $21 \mathrm{st}$ century.

Regime shifts in winter temperature in Estonia have caused shifts in specific runoff of rivers (Table 7). Warmer winters are naturally related to higher runoff in winter and earlier maximum in spring after the snowmelt that is typical for Estonia. Usually it has been observed in April but during the last decades it has shifted to March. As a consequence, runoff in March has a positive shift, which causes the negative shift in April. In 14 of 21 stations, upward regime shifts in runoff appeared starting in the winters of 1988/1989 or $1987 / 1988$ (Fig. 2). The same shift was also present in January, February and March. The consistent upward regime shifts in specific runoff appeared in 19 of 21 stations beginning March 1989, which has been the most prominent change despite the high variability in hydrological and hydrogeological conditions in watersheds analysed in this study. The increase in runoff in March is closely related to the decrease in 
Table 7. Trend values of mean monthly, annual and seasonal specific runoff averaged over the 21 stations in Estonia. Statistically significant trends at the $p<0.05$ level are in bold. Shift years, mean shift values and numbers of stations with statistically significant regime shifts in specific runoff.

\begin{tabular}{|c|c|c|c|c|c|c|c|}
\hline & \multirow[t]{2}{*}{ Trend } & \multicolumn{3}{|c|}{ Upward shift } & \multicolumn{3}{|c|}{ Downward shift } \\
\hline & & Year & No. of stations & Value & Year & No. of stations & Value \\
\hline Jan & 0.78 & 1988 & 14 & 7.1 & & & \\
\hline Feb & 0.41 & 1989 & 10 & 6.6 & 2003 & 4 & -8.7 \\
\hline Mar & 0.68 & 1989 & 19 & 7.0 & 2003, 2009 & 6 & -7.9 \\
\hline Apr & -0.50 & 2009,2010 & 14 & 11.2 & 1989 & 8 & -11.8 \\
\hline May & -0.31 & & & & & & \\
\hline Jun & 0.08 & & & & & & \\
\hline Jul & 0.04 & & & & & & \\
\hline Aug & 0.02 & & & & & & \\
\hline Sep & -0.01 & & & & & & \\
\hline Oct & -0.08 & & & & 1964 & 3 & -3.5 \\
\hline Nov & 0.13 & 1977 & 3 & 7.7 & 1992 & 3 & -6.4 \\
\hline Dec & 0.29 & 2003 & 6 & 8.8 & 1963 & 3 & -3.2 \\
\hline Year & 0.17 & 1978,1981 & 9 & 2.9 & 1964 & 8 & -2.0 \\
\hline Spring & -0.13 & 2010 & 5 & 4.7 & 1963 & 4 & -4.4 \\
\hline Summer & 0.05 & & & & & & \\
\hline Autumn & -0.02 & & & & & & \\
\hline Winter & 0.65 & 1988,1989 & 14 & 5.0 & & & \\
\hline
\end{tabular}

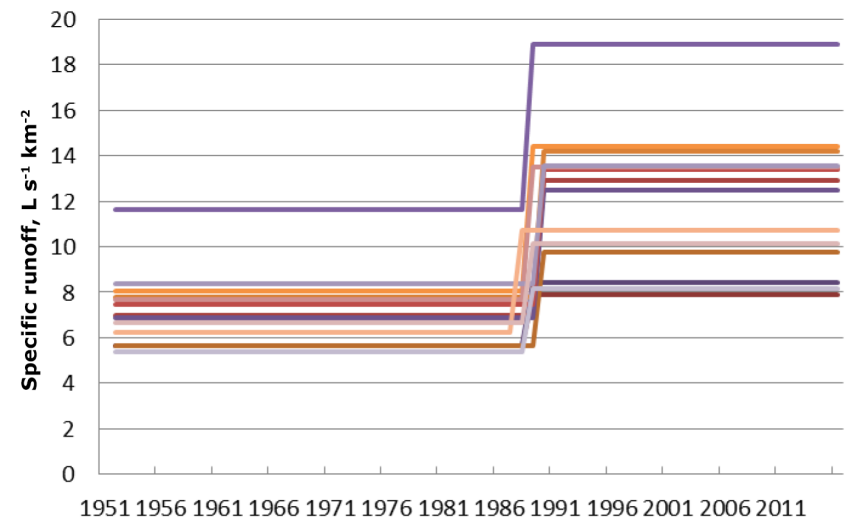

Figure 2. Regime shifts in winter (DJF) specific runoff of rivers in 14 stations where a statistically significant shift was detected in $1987 / 1988$ or $1988 / 1989$.

April starting in 1989 with the return shift in the end of the time series beginning 2009 or 2010 (Fig. 3). During the other months there were practically no significant regime shifts in specific runoff.

\section{Discussion}

It is rather natural that the elements of the climate system air temperature, precipitation, snow cover, river runoff and indices of the large-scale atmospheric circulation - have close relationships. Changes in some parameters will in-

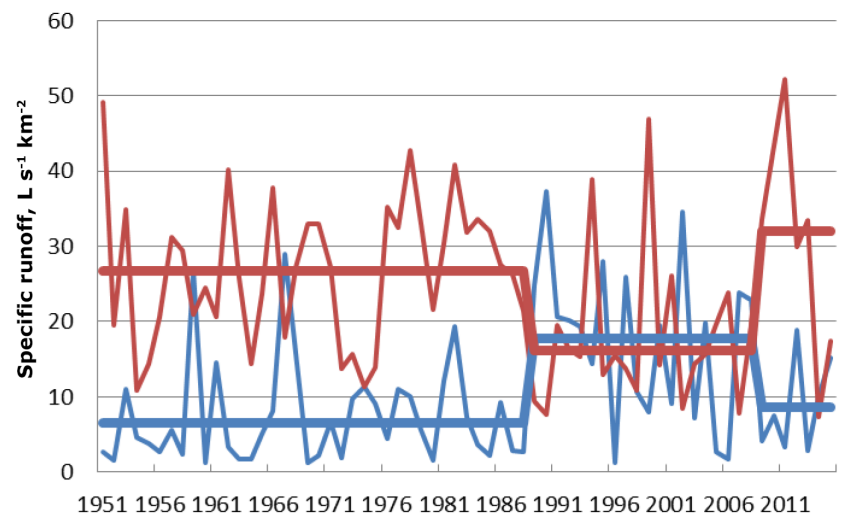

Figure 3. Time series of specific runoff $\left(\mathrm{Ls}^{1} \mathrm{~km}^{-2}\right)$ in March (blue) and April (red) at Riisa station on the Halliste River during 1951-2015 and their regime shifts of opposite sign since 1989 and 2009 (wide lines).

duce corresponding changes in other parameters. We analysed correlations between them, similarities in their trends and regime shifts in Estonia. This kind of local-scale integrated analysis of trends and regime shifts in time series of many inter-related and indicative variables of the climate system starting is innovative, enabling detection of general regularities of a long-term environmental change.

The character of the large-scale atmospheric circulation is the main factor causing a very high interannual variability in weather conditions in the region. The highest role of circu- 
lation can be observed during the cold season when the role of solar radiation is negligible due to the high latitude of the study region. The Atlantic Ocean is virtually the only source of warm air for northern Europe in winter. Winter weather conditions in Estonia are largely determined by the intensity of westerly circulation over the Atlantic/European sector causing the advection of comparatively warm and moist air from the ocean. In the case of weakening of the westerlies, the influence of the ocean decreases and weather is formed under the influence of a cold and dry continental air mass.

The AO and NAO indices are appropriate variables for describing the intensity of westerlies. They have high correlations with winter climatic and hydrological parameters in Estonia. First of all, they determine temperature conditions in winter. Snow cover duration is directly dependent on temperature, while precipitation has more indirect relationships. Higher temperature in winter is caused by the cyclonic weather situation. It is related to cloudy, windy and rainy (snowy) conditions with higher precipitation. We detected increasing trends and upward regime shifts in $\mathrm{AO}$ and $\mathrm{NAO}$ indices in winter months and for the winter season as a whole. This reflects the intensification of the westerly circulation that abruptly occurred beginning in the winter of 1988/1989.

Changes in large-scale atmospheric circulation, trends and regime shifts have naturally caused changes in other parameters. For example, the intensification of westerly circulation in winter during 1951-2015 induced a significant increase in winter and spring temperature as well as winter precipitation and river runoff and a decrease in snow cover duration. It is expressed by linear trends and even better by coherent regime shifts starting in the late 1980s. The shift year 1989 was found for the majority of time series analysed in this study. This result is in good concordance with the previous investigations in the same region (Keevallik and Soomere, 2008; 2014; Elken et al., 2014; Soomere et al., 2015).

The results of the trend analysis confirm the fact that climate warming in the Baltic Sea region has been faster than the global mean (BACC, 2015). Trend values of $0.3-$ $0.4^{\circ} \mathrm{C}$ decade $^{-1}$ for annual mean temperature and the maximum of more than $0.6^{\circ} \mathrm{C}$ in March show the existence of a very rapid change during 1951-2015. In comparison with the previous analysis (Jaagus, 2006) the warming trend has intensified during the last 15 years annually as well as monthly and seasonally. The only exception is spring. The trend in March and spring mean temperature in Estonia during 19512015 is much lower than in 1951-2000. At the same time, mean temperature in summer and autumn had no trend in 1951-2000 (Jaagus, 2006), but a statistically significant trend appeared when we used the updated time series (Table 4).

In the majority of cases with significant trends, a regime shift was also detected. This allows assuming that the climate change is not a monotonic process but consists of abrupt changes. Several return shifts, i.e. shifts of an opposite direction, were also found. In these cases the initial regime was more or less re-established. The shift value of about $2{ }^{\circ} \mathrm{C}$ for winter temperature is practically the same as the total change by trend. This means that the whole winter warming during 1951-2015 can be described by the regime shift starting in $1988 / 1989$.

It is important to emphasise the differences between the coastal zone and the continental part of Estonia. The winter warming has been higher in the continent and lower near the coast of the Baltic Sea. This can be explained by the thermal inertia of the sea and by the fact that, in the case of stronger westerly circulation, the advection of a mild and moist maritime air mass into the continental parts of Estonia causes more substantial change in weather conditions than in the coastal zone. At the same time correlation between the circulation indices and mean temperature is much higher at the coast.

Snow cover duration has a highly negative correlation with air temperature in winter. Therefore, the decrease by 3-4 days decade ${ }^{-1}$ and the downward regime shift by 1620 days since the winter of 1988/1989 follow the changes in temperature during the study period. The trend in snow cover duration in Estonia has not changed in comparison with the results of the previous study (Jaagus, 2006). Snow cover duration has continued to decrease using the updated time series.

Various results of the analysis of trends and regime shifts for precipitation can be explained by its extremely high spatial and temporal variability. Mostly increasing trends appeared in the case of winter months. It is natural because higher winter temperature in Estonia is related to cyclonic weather conditions that are also explained by higher cloudiness, wind speed and precipitation. The results of the trend analysis are in line with the previous study. The only exception is November, when precipitation significantly increased during the longer period (Table 4). Regime shifts in precipitation are not coherent in the stations. They reflect long-term fluctuations. For example, the start of a rainy period in the end of the 1970s and in the beginning of the 1980s is characterised by an upward shift in annual precipitation detected in many stations. Similar regime shifts were also found for the three Baltic countries (Jaagus et al., 2016).

Annual mean runoff has not revealed any strong trends or shifts in spite of the increased precipitation and temperature. However, there are clear seasonal changes found in several earlier studies and confirmed in the current one. Specific runoff has significantly increased for the winter season and in all winter months separately from December to March. The highest increase occurred in western Estonia. As the most important change in the hydrological regime of rivers, the maximum spring runoff has moved from May and April to March due to milder winters and earlier snowmelt. It could be considered as a logical consequence of climate warming that is projected in Estonia for the end of this century (Jaagus et al., 1998; Jaagus and Mändla, 2014). 
Despite the comparatively small territory, quite obvious spatial differences were found in regime shifts in Estonia. The Vasknarva station on the Narva River reflects runoff fluctuations over a much wider area than the territory of Estonia buffered by Lake Peipsi. Therefore, they are not well comparable with shifts in other stations. Much less statistically significant regime shifts were detected in specific runoff in northern Estonia (Jägala, Valgejõgi, Kunda and Purtse rivers) than in the other parts of Estonia. Upward shifts were revealed there only in March beginning in 1989. Rivers in northern Estonia are also characterised by strong decreasing trends in specific runoff in May.

The second group consists of Vihterpalu, Leivajõgi and Keila rivers in north-western Estonia, where shifts were also detected in January, February and winter as a whole. Rivers in western Estonia (Kasari, Pärnu, Lõve) have the strongest regime shifts. The Kasari and Lõve rivers have extremely high shift values, which exceed $11 \mathrm{~L} \mathrm{~s}^{-1} \mathrm{~km}^{-} 2$ in January and February. Positive shifts at these stations were also revealed in annual runoff. Two other groups of rivers were distinguished in central Estonia (Pedja, Põltsamaa, Navesti) and southern Estonia (Võhandu, Piigaste, Väike-Emajõgi, Õhne, Halliste). Both groups can be characterised by positive regime shifts in January and March and a negative shift in April since the end of the 1980s, but in southern Estonia there are also shifts in February and June.

One peculiarity of the STARS method (Rodionov test) is the fact that it does not give reliable results for the end of the time series. Therefore, using the updated time series permits us to confirm that the regime shifts at the end of the 1980s have really taken place.

\section{Conclusions}

The main result of this study is the detection of coherent regime shifts in many climatic and hydrological parameters in Estonia that mainly occurred starting from the winter of 1988/89. This significant change was caused by an abrupt intensification of westerlies described by the $\mathrm{AO}$ and NAO indices, which has brought a bigger amount of warm air from the North Atlantic to the Baltic Sea region. As a consequence, winter air temperature has increased significantly and the duration of snow cover has decreased. Due to the thermal inertia mild winters are followed by early and warmer springs. The warming trend has been mentioned throughout the year, but it is the highest in winter and spring. The shift value of about $2{ }^{\circ} \mathrm{C}$ for winter temperature and up to 20 days for snow cover duration detected in the end of the 1980 s is nearly similar to the total change by trend in 19512015.

Precipitation can be described by a moderate increase observed during the cold season (from November to March) and June, as well as by various regime shifts. Annual precip- itation has shift years starting in 1977 at some stations and winter precipitation beginning at the end of the 1980s.

Changes in climatic parameters were reflected in specific runoff of rivers. Winter runoff has increased significantly and especially in March. The runoff maximum caused by snowmelt has shifted from April to March and runoff in April has decreased. There were few changes in specific runoff during the warm half-year.

Data availability. All meteorological and hydrological data from Estonia used in this study have been provided by the Estonian Weather Service. We have no permission to make them publicly accessible. The data on large-scale atmospheric circulation have been obtained from the following web pages: http://www.cpc.ncep.noaa.gov/data/teledoc/telecontents.shtml (CPC, 2017a), http://www.cpc.noaa.gov/products/precip/ CWlink/daily_ao_index/monthly.ao.index.b50.current.ascii.table (CPC, 2017b), https://climatedataguide.ucar.edu/climate-data/ hurrell-north-atlantic-oscillation-nao-index-station-based (Hurrell and National Center for Atmospheric Research, 2017) and https://crudata.uea.ac.uk/cru/data/nao/ (Climate Research Unit, 2017).

Competing interests. The authors declare that they have no conflict of interest.

Special issue statement. This article is part of the special issue "Multiple drivers for Earth system changes in the Baltic Sea region". It is a result of the 1st Baltic Earth Conference, Nida, Lithuania, 13-17 June 2016.

Acknowledgements. This study was done using the financial support of the European Regional Development Fund (project EstKliima of the Environmental Protection and Technology Programme no. 3.2.0802.11-0043), the EU JPI WATER project IMDROFLOOD and the institutional research grant IUT2-16 of the Estonian Research Council.

Edited by: Anna Rutgersson

Reviewed by: two anonymous referees

\section{References}

Alheit, J., Möllmann, C., Dutz, J., Kornilovs, G., Loewe, P., Mohrholz, V., and Wasmund, N.: Synchronous ecological regime shifts in the central Baltic and the North Sea in the late 1980s, ICES Journal of Marine Science, 62, 1205-1215, 2005.

BACC: Assessment of climate change for the Baltic Sea basin, Springer-Verlag, Berlin Heidelberg, 473 pp., 2008.

BACC: Second assessment of climate change for the Baltic Sea basin. Springer, Cham Heidelberg New York Dordrecht London, 501 pp., 2015. 
Barnston, A. G. and Livezey, R. E.: Classification, seasonality and persistence of low-frequency atmospheric circulation patterns, Mon. Weather Rev., 115, 1083-1126, 1987.

Biggs, R., Carpenter, S. R., and Brock, W. A.: Turning back from the brink: Detecting an impending regime shift in time to avert it, P. Natl. Acad. Sci. USA, 106, 826-831, 2009.

Conversi, A., Fonda Umani, S., Peluso, T., Molinero, J. C., Santojanni, A., and Edwards, M.: The Mediterranean Sea regime shift at the end of the $1980 \mathrm{~s}$, and intriguing parallelisms with other European basins, Plos One, 5, 1-13, https://doi.org/10.1371/journal.pone.0010633, 2010.

CPC (Climate Prediction Center): NOAA/National Weather Service, CPC Dataset, available at: http://www.cpc.ncep.noaa.gov/ data/teledoc/telecontents.shtml, last access: 2 November 2017a.

CPC (Climate Prediction Center): NOAA/National Weather Service, CPC Dataset, available at: http://www.cpc.noaa.gov/ products/precip/CWlink/daily_ao_index/monthly.ao.index.b50. current.ascii.table, last access: 2 November $2017 \mathrm{~b}$.

Climate Research Unit: University of East Anglia, CRU Dataset, available at: https://crudata.uea.ac.uk/cru/data/nao/, last access: 2 November 2017.

DeYoung, B., Harris, R., Alheit, J., Beaugrand, G., Mantua, N., and Shannon, L.: Detecting regime shifts in the ocean: data considerations, Prog. Oceanogr., 60, 143-164, 2004.

Dippner, J. W., Möller, C., and Hänninen, J.: Regime shifts in North Sea and Baltic Sea: A comparison, J. Marine Syst., 105-108, 115-122, 2012.

Drinkwater, K. F.: The regime shift of the 1920s and 1930s in the North Atlantic, Prog. Oceanogr., 68, 134-151, 2006.

Elken, J., Raudsepp, U., Laanemets, J., Passenko, J., Maljutenko, I., Pärn, O., and Keevallik, S.: Increased frequency of wintertime stratification collapse events in the Gulf of Finland since the 1990s, J. Marine Syst., 129, 47-55, 2014.

Hagen, E. and Feistel, R.: Climatic turning points and regime shifts in the Baltic Sea region: the Baltic winter index (WIBIX) 16592002, Boreal Environ. Res., 10, 211-224, 2005.

Hare, S. R. and Mantua, N. J.: Empirical evidence for North Pacific regime shifts in 1977 and 1989, Prog. Oceanogr., 47, 103-145, 2000 .

Huntington, T. G.: Evidence for intensification of the global water cycle: review and synthesis, J. Hydrol., 1, 83-95, 2006.

Hurrell, J. W.: Decadal trends in the North Atlantic oscillation: regional temperatures and precipitation, Science, 269, 676-679, 1995.

Hurrell, J. W. and Deser, C.: North Atlantic climate variability: The role of the North Atlantic Oscillation, J. Marine Syst., 78, 28-41, 2009.

Hurrell, J. and National Center for Atmospheric Research: The Climate Data Guide: Hurrell North Atlantic Oscillation (NAO) Index, available at: https://climatedataguide.ucar.edu/climate-data/ hurrell-north-atlantic-oscillation-nao-index-station-based, last access: 2 November 2017.

Jaagus, J.: Periodicity of precipitation in Estonia, Estonia. Man and Nature, 6, 43-53, 1992.

Jaagus, J.: Climatic fluctuations and trends in Estonia in the 20th century and possible climate change scenarios, in: Climate change studies in Estonia, edited by: Kallaste, T. and Kuldna, P., Tallinn, Stockholm Environment Institute Tallinn Centre, 7-12, 1998.
Jaagus, J.: Climatic changes in Estonia during the second half of the 20th century in relationship with changes in large-scale atmospheric circulation, Theor. Appl. Climatol., 83, 77-88, 2006.

Jaagus, J., Briede, A., Rimkus, E., and Remm, K.: Precipitation pattern in the Baltic countries under the influence of large-scale atmospheric circulation and local landscape factors, Int. J. Climatol., 30, 705-720, 2010.

Jaagus, J., Briede, A., Rimkus, E., and Sepp, M.: Changes in precipitation regime in the Baltic countries in 1966-2015, Theor. Appl. Climatol., https://doi.org/10.1007/s00704-016-1990-8, 2016.

Jaagus, J., Järvet, A., and Roosaare, J.: Modelling the climate change impact on river runoff in Estonia, in: Climate change studies in Estonia, edited by: Kallaste, T. and Kuldna, P., Tallinn, Stockholm Environment Institute Tallinn Centre, 117-126, 1998.

Jaagus, J. and Mändla, K.: Climate change scenarios for Estonia based on climate models from the IPCC Fourth Assessment Report, Est. J. Earth Sci., 63, 166-180, 2014.

Järvet, A.: Long-term changes in time series of water balance elements, in: Country Case Study in Climate Change Impacts and Adaptation Assessments in the Republic of Estonia, Report to the UNEP/GEF Project N.: GF/2200-96-45, 69-71, 1998.

Jones, P. D., Jónsson, T., and Wheeler, D.: Extension to the North Atlantic Oscillation using early instrumental pressure observations from Gibraltar and South-West Iceland, Int. J. Climatol., 17, 1433-1450, 1997.

Keevallik, S.: Shifts in meteorological regime of the late winter and early spring in Estonia during recent decades, Theor. Appl. Climatol., 105, 209-215, 2011.

Keevallik, S. and Soomere, T.: Shifts in early spring wind regime in North-East Europe (1955-2007), Clim. Past, 4, 147-152, https://doi.org/10.5194/cp-4-147-2008, 2008.

Keevallik, S. and Soomere, T.: Regime shifts in the surface-level average air flow over the Gulf of Finland during 1981-2010, P. Est. Acad. Sci., 63, 428-437, 2014.

Keevallik, S. and Vint, K.: Influence of changes in the station location and measurement routine on the homogeneity of the temperature, wind speed and precipitation time series, Estonian Journal of Engineering, 18, 302-313, 2012.

Kendall, M. G.: Rank Correlation Methods, Griffin, London, 1975.

Kerr, R. A.: Unmasking a shifty climate system, Science, 255, 1508-1510, 1992.

Kim, Y.-H., Kim, M.-K., Lau, W. K. M., Kim, K.-M., and Cho, C.-H.: Possible mechanism of abrupt jump in winter surface air temperature in the late 1980 s over the Northern Hemisphere, J. Geophys. Res.-Atmos., 120, 12474-12485, 2015.

Kriaučiuniene, J., Meilutyte-Barauskiene, D., Reihan, A., Koltsova, T., Lizuma, L., and Sarauskiene, D.: Variability in temperature, precipitation and river discharge in the Baltic States, Boreal Environ. Res., 17, 150-162, 2012.

Labat, D., Goddéris, Y., Probst, J. L., and Guyot, J. L.: Evidence for global runoff increase related to climate warming, Adv. Water Resour., 27, 631-642, 2004.

Lehmann, A., Getzlaff, K., and Harlaß, J.: Detailed assessment of climate variability in the Baltic Sea area for the period 1958 to 2009, Clim. Res., 46, 185-196, 2011.

Lo, T. and Hsu, H.: Change in the dominant decadal patterns and the late 1980s abrupt warming in the extratropical Northern Hemisphere, Atmos. Sci. Lett., 11, 210-2015, 2010. 
Mann, H. B.: Nonparametric tests against trend, Econometrica, 13, 245-259, 1945.

Mantua, N., Hare, S., Zhang, Y., Wallace, J., and Francis, R.: A Pacific interdecadal climate oscillation with impacts on salmon production, B. Am. Meteorol. Soc., 78, 1069-1079, 1997.

Möllmann, C., Diekmann, R., Müller-Karulis, B., Kornilovs, G., Plikshs, M., and Axe, P.: Reorganization of a large marine ecosystem due to atmospheric and anthropogenic pressure: a discontinuous regime shift in the Central Baltic Sea, Glob. Change Biol., 15, 1377-1393, 2009.

Overland, J. E., Rodionov, S., Minobe, S., and Bond, N.: North Pacific regime shifts: Definitions, issue and recent transitions, Prog. Oceanogr., 77, 92-102, 2008.

Reid, P. C., Hari, R. E., Beaugrand, G., Livingstone, D. M., Marty, C., Straile, D., Barichivich, J., Goberville, E., Adrian, R., Aono, Y., Brown, R., Foster, J., Groisman, P., Hélaouët, P., Hsu, H.-H., Kirby, R., Knight, J., Kraberg, A., Li, J., Lo, T.-T., Myneni, R. B., North, R. P., Pounds, J. A., Sparks, T., Stübi, R., Tian, Y., Wiltshire, K. H., Xiao, D., and Zhu, Z.: Global impacts of the 1980s regime shift, Glob. Change Biol., 22, 682-703, 2016.

Reihan, A., Kolcova, T., Kriauciuniene, J., Meilutyte-Barauskiene, D., and Järvet, A.: Changes in river runoff in Baltic States in 20th century, Nordic Hydrology Programme Report, 49: Nordic Water 2006 - The XXIV Nordic Hydrological Conference, Denmark, 6-9 August, 601-608, 2006.

Reihan, A., Koltsova, T., Kriauciuniene, J., Lizuma, L., and Meilutyte-Barauskiene, D.: Changes in water discharges of the Baltic States rivers in the 20th century and its relation to climate change, Nord. Hydrol., 38, 401-412, 2007.

Reihan, A., Kriauciuniene, J., Meilutyte-Barauskiene, D., and Kolcova, T.: Temporal variation of spring flood in rivers of the Baltic States, Hydrol. Res., 43, 301-314, 2012.

Rodionov, S. N.: A sequential algorithm for testing climate regime shifts, Geophys. Res. Lett., 31, L09204, https://doi.org/10.1029/2004GL019448, 2004.

Rodionov, S. N.: A brief overview of the regime shift detection methods, in large-scale disturbances (regime shifts) and recovery in aquatic ecosystems, in: Challenges for Management Towards Sustainability, edited by: Velikova, V. and Chipev, N., U.N. Educ., Sci., and Cult. Organ., Paris, 17-24, 2005.

Rodionov, S. N. and Overland, J. E.: Application of a sequential regime shift detection method to the Bering Sea ecosystem, ICES Journal of Marine Science, 62, 328-332, 2005.
Rodwell, M. J., Rowell, D. P., and Folland, C. K.: Oceanic forcing of the wintertime North Atlantic oscillation and European climate, Nature, 398, 320-323, 1999.

Rutgersson, A., Jaagus, J., Schenk, F., and Stendel, M.: Observed changes and variability of atmospheric parameters in the Baltic Sea region during the last 200 years, Clim. Res., 61, 177-190, 2014.

Sen, P. K.: Estimates of the regression coefficient based on Kendall's tau, International Journal of American Statistical Association, 63, 1379-1389, 1968.

Sits, M. and Post, P.: Comparison of air temperatures measured at three Tartu meteorological stations, Publicationes Geophysicales Universitatis Tartuensis, 50, 205-214, 2006.

Soomere, T., Bishop, S. R., Viška, M., and Räämet, A.: An abrupt change in winds that may radically affect the coasts and deep sections of the Baltic Sea, Clim. Res., 62, 163-171, 2015.

Soomere, T. and Räämet, A.: Decadal changes in the Baltic Sea wave heights, J. Marine Syst., 129, 86-95, 2014.

Swanson, K. L., and Tsonis, A. A.: Has the climate recently shifted?, Geophys. Res. Lett., 36, L06711, https://doi.org/10.1029/2008GL037022, 2009.

Tanaka, H. L., Kanohgi, R., and Yasunari, T.: Recent abrupt intensification of the northern polar vertex since 1988, J. Meteorol. Soc. Jpn., 74, 947-954, 1996.

Thompson, D. W. and Wallace, J. M. The Arctic Oscillation signature in the wintertime geopotential height and temperature fields, Geophys. Res. Lett., 25, 1297-1300, 1998.

Tsunoda, T., Kawahata, H., Suzuki, A., Minoshima, K., and Shikazono, N.: East Asian Monsoon to El Niño/Southern Oscillation: a shift in the winter climate of Ishigaki Island accompanying the 1988/1989 regime shift, based on instrumental and coral records, Geophys. Res. Lett., 35, L13708, https://doi.org/10.1029/2008GL033539, 2008.

Walsh, J. E., Chapman, W. L., and Shy, T. L.: Recent decrease of sea level pressure in the central Arctic, J. Climate, 9, 480-486, 1996.

Watanabe, M. and Nitta, T.: Decadal changes in the atmospheric circulation and associated surface climate variations in the Northern Hemisphere winter, J. Climate, 12, 494-510, 1999.

Yasunaka, S. and Hanawa, K.: Regime shifts found in the Northern Hemisphere SST field, J. Meteorol. Soc. Jpn., 80, 119-135, 2002. 